\title{
XI JINPING'S AUTHORITARIANISM, CHINESE FOREIGN POLICY AND INDIA
}

China's President Xi Jinping has placed great emphasis on power consolidation, focusing on domestic restructuring to enhance the centrality of the Chinese Communist Party (CCP) and its communist ideology. This has compelled political pundits to mull over the bearing of a strong authoritarian Chinese regime on Xi Jinping's foreign policy. China is already casting strong regional maritime advances and leveraging its economic might over its continental periphery. In this regard, tensions are rising in the Indo-Pacific region with countries like India and Japan coalescing to negate China's assertiveness. Nonetheless, the new security architecture of Asia demands balanced strategic manoeuvring, exemplified by China and India pushing their bilateral ties forward while striking new deals with other like-minded countries.

Keywords: Xi Jinping, authoritarianism, Chinese foreign policy, Xi's presidency, Indian foreign policy, India-China relations

Jawaharlal Nehru University, India; atmaja46@gmail.com

East Asia, Institute for Defence Studies and Analyses [IDSA], India; jppjagannath@gmail.com 


\section{Introduction}

At the 19th National Congress of the Communist Party of China (CPC) convened in October 2017, the CPC's Constitution conferred on Xi Jinping an astounding measure of ideological authority by revising the constitution and imbibing "Xi Jinping Thought on Socialism with Chinese Characteristics for a New Era" as the CPC's new guidebook. In October 2016, he was given the special stature of being a "Core Leader" of China, already setting him apart from his predecessors. ${ }^{2}$ It was Deng Xiaoping who had coined the term "core" leader for himself, Mao Zedong and Jiang Zemin, meaning that their authority was almost absolute and unquestionable. So, now in 2018, with the revision of the President's and the Vice President's term limits while bestowing complete control of all the key pillars of the Chinese nation - the government, party and the army - to the President, there can be no better time than now for Xi Jinping, allegedly the most powerful leader after Mao in Chinese political history, to occupy office for as many terms as he cherishes after his coming term officially concludes in 2023. This will be a pivotal moment in China's history - Xi will become the longest serving leader after Mao. ${ }^{3}$ Moreover, with no strong opposition from the elite, one can only expect him to reinforce his authority to the optimum.

Ever since he came to rule in 2012, there has been rapid consolidation of Xi's power, starting from 2013, when he began heading the Special Leading Group taking care of economic reforms ${ }^{4}$, to appointing himself the commander-inchief of the Chinese military, even though as the Central Military Commission head, he was already in charge of the armed forces. ${ }^{5}$

$1 \quad$ Full text of Xi Jinping's report at the 19th CPC National Congress: "Secure a Decisive Victory in Building a Moderately Prosperous Society in All Respects and Strive for the Great Success of Socialism with Chinese Characteristics for a New Era", 10/2017; "Incorporation of $\mathrm{Xi}$ Jinping Thought into Constitution Conducive to National Rejuvenation", People's Daily, 2/2018, http://en.people.cn/n3/2018/0226/c900009430280.html (27.5.2018).

2 “China's Xi appointed 'core' leader, on par with Mao, Deng”, Reuters, 10/2016, https:// www.reuters.com/article/us-china-politics/chinas-xi-anointed-core-leader-on-par-withmao-deng-idUSKCN12R1CK, (27.5.2018).

3 Li Ruohan, Bai Yunyi: “China adopts Constitutional amendment”, Global Times, 3/2018, http://www.globaltimes.cn/content/1092805.shtml, (27.5.2018); “Amendments proposed for Constitution”, China Daily, 2/2018, http://www.chinadaily.com.cn/a/201802/25/ WS5a927386a3106e7dcc13dece.html (27.5.2018).

4 "China Reform Pledges Show Xi Assuming Deng Mantle, Analysts Say", South China Morning Post, 11/ 2013, https://www.rappler.com/world/regions/asia-pacific/44091-chinaeconomy-policy-reform-xi-jinping-analysis, (27.5.18)

5 "Xi Jinping named as "commander in chief" by Chinese state media", The Guardian, 4/2016, https:/www.theguardian.com/world/2016/apr/21/xi-jinping-named-commanderin-chief-chinese-state-media, (27.5.2018). 
Understanding various domestic changes in China is crucial. Being the number two power globally and much keen on becoming number one, China shapes its policies in an integral way for securing world peace and security. Its foreign policy relevance as well is much consequential, most significantly, the development of Xi's most important master project - the Belt and Road Initiative (BRI). For the BRI's success, China has aligned itself with numerous countries for matters of economy, defence and security. The "new era" strategy - to re-establish China in the world order and make it a powerful state to reckon with - exemplifies this. In its pursuit, Beijing has been engaging in a multipronged foreign policy, juxtaposing "bringing-in" and "going-out" policies. ${ }^{6}$ While "bringing-in" involves hosting grand affairs and holding meetings with foreign delegates, the "going-out" strategy involves the leadership and bureaucrats making overseas visits through outreach programmes comprising signing of multifarious agreements and deals, engaging in cooperative programmes and fostering investment abroad.

This paper will first focus on the various domestic developmental reforms taking place in China which are strengthening Xi's rule and hence, the existing authoritarian regime. ${ }^{7}$ Secondly, it will seek to unearth what took place in China domestically from $\mathrm{Hu}$ Jintao's period to Xi Jinping's, to bring forth such rapid transformations. Revisiting the past helps in uncovering the ambiguities of the present. Thirdly, there will be an attempt to comprehend the consequences of China's assertive stance on neighbouring middle powers, particularly India, and how most of their positions are hinged on China's political manoeuvres. An in-depth analysis of these issues will give a deeper understanding of how middle powers like India can position themselves more progressively to deal with a seemingly insatiable China.

\section{Domestic Restructuring - Implications of authoritarianism in China}

The last time the constitution was amended was in March 2004 at the Second Session of the Tenth National People's Congress; the current amendment is the fifth occasion that the constitution is being amended. ${ }^{8}$ It has been referred to as an "important" development in China's political functioning, played safely by Xi

6 Xie Tao: "Chinese Foreign Policy with Xi Jinping Characteristics", Carnegie Endowment for International Peace, 11/2017, http://carnegieendowment. org/2017/11/20/chinese-foreign-policy-with-xi-j.(27.5.2018).

7 This paper is an extension of the issue brief published by Jagannath P. Panda in IDSA. Please see, Panda Jagannath, "Xi Jinping's Extended Presidency and India-China Relations", IDSA Issue Brief, 3/2018, https://idsa.in/issuebrief/xi-jinping-extended-presidency-indiachina-relations_jppanda_270318, (27.5.2018).

8 "Constitution of the People's Republic of China" The State Council PRC http://english.gov. cn/archive/laws_regulations/2014/08/23/content_281474982987458.htm, (27.5.2018). 
by not contravening any laws around age but still retaining his personal allies in the Politburo. ${ }^{9}$ The focus of the Chinese state media is mostly directed towards the idea that the amendment has not changed the retirement age of the party officials, but represents an extremely progressive move fortifying Xi's rise as the leader of the CPC.

He has already manifested Xi Jinping's Thought on "Socialism with Chinese Characteristics for an Era" ${ }^{\text {"10 }}$ into the party's constitution, which basically entails China establishing a "moderately prosperous society" by 2020 , becoming a great modern socialist country by 2035 and, eventually, restoring its strength by the middle of the 21st century. ${ }^{11}$ The ideological tightening of the amendment has been reflected in the charter of the Chinese People's Political Consultative Conference (CPPCC) as well - an advisory structure of the party. ${ }^{12}$ Thus, it has ramifications for all of China's political, economic, diplomatic, social and military reforms.

According to Cheng Enfu, a deputy to the 13th NPC and a professor at the Chinese Academy of Social Sciences, "China has unfinished economic, political, diplomatic and military reforms, and the country needs a determined and innovative State leader to accomplish such goals". ${ }^{13}$ Before delving any further, it is important to question what authoritarian regimes fundamentally mean and how they actually function.

Authoritarian regimes in their broadest sense include all patterns of undemocratic rule where the institutions of political competition, control and monitoring of power and participation do not exist. Individuals do not have fundamental rights or constitutional accountability and their freedom is always subordinate to the state. ${ }^{14}$ These are however different from totalitarian regimes, which involve rule over everything - from political to apolitical aspects

$9 \quad$ Stanzel Angela et al: “China's New Era with Xi Jinping's characteristics”, European Council on Foreign Relations, 12/2017, http://www.ecfr.eu/publications/summary/chinas_new_ era_with_xi_jinping_characteristics7243, (27.5.2018); Zhao Yusha:“Communique notes China at 'new historical starting point' for China" Global Times, 10/ 2017, http://www. globaltimes.cn/content/1070429.shtml, (27.5.2018).

10 "Compilation of Xi Jinping's remarks on youth and the work of the Communist Youth League”, Beijing, Central Party Literature Press, 2017.

11 An Baijie: "Xi pledges 'new era' in building moderately prosperous society", China Daily, 10/2017, http://www.chinadaily.com.cn/china/2017-10/19/content_33428169.htm, (27.5.2018).

12 "Proposed Amendment to CPPCC Charter Unveiled", Xinhua, 3/2018, http://www. xinhuanet.com/english/2018-03/08/c_137025376.htm, (27.5.2018).

13 Li Ruohan, Bai Yunyi: “China Adopts Constitutional Amendment”, Global Times, 3/2018, http://www.globaltimes.cn/content/1092805.shtml, (27.5.2018).

14 Ginsburg Tom, Simpser Alberto (2014): "Introduction, Chapter 1 of Constitutions in Authoritarian Regimes", University of Chicago Public Law \& Legal Theory Working Paper No. 468/ 9-11. 
of life..$^{15}$ An authoritarian regime may hold an election but citizens do not have any say in its outcome. The state apparatus is usually coercive, especially when faced with external or internal threats. ${ }^{16}$ How the threat is calculated depends on the resilience of the state's political institutions and civil-military relations. In regimes characterised by weak political institutions and conflictprone civil-military relations, threats are perceived more gravely and military organisational practices are adopted.$^{17}$ Such militaries maximise their capabilities by conducting rigorous trainings, by capitalising on improving capacity and military specialisations, ensuring that command is unified and decentralised. ${ }^{18}$ To evoke Charles Tilly's dictum, for an authoritarian regime "war made the state and the state made war".

Since regime stability is the most important for the sustenance of the leader's rule and security, external threats are considered more severely than internal ones. Occurrences like rural insurgencies or street protests are usually not perceived to be as perilous as an external threat assessment or a military coup. Moreover, as social protests may take several years to garner support, while offering opportunities for making peace through negotiations, their occurrence is not considered much dangerous for regime stability. The case of China, more or less, validates all of these arguments of what makes a country hard authoritarian. Nothing is more important for China than maintaining regime stability - it not only prohibits social protests but strictly controls the circulation of data too, except for state-sponsored media. Too much liberty or access to information is seen as a potential destabiliser of the regime. ${ }^{19}$

Xi's present rule points towards a unified, much consolidated leadership in times to come. Since he joined office, Xi has slowly but successfully consolidated his power by not only exercising power in the party and the military but also heading other Leading Groups and commissions. While previously economic and financial affairs were controlled by Premier Li Keqiang, the state of the current political structure witnesses Xi Jinping exercising leadership in almost all sectors. $^{20}$

15 Friedrich Carl J, Brzezinski, Zbigniew K. (1956): Totalitarian Dictatorship and Autocracy, New York, 367-368.

16 For a theoretical discussion of authoritarian military regimes, see Talmadge Caitlin (2016): "Different Threats, Different Militaries: Explaining organizational practices in authoritarian regimes", Security Studies, 25:111-141.

17 Huntington Samuel P. (1957):The Soldier and the State: The Theory and Politics of CivilMilitary Relations, Cambridge, 80-98, MA: Harvard University Press, the United States.

18 Talmadge Caitlin, 4.

19 Ginsburg Tom, Simpser Alberto, 4.

20 Huang Zheping: "China's President Xi Jinping Now Has a Dozen Titles, and Counting”, Quartz, 1/ 2017, https://qz.com/892208/chinas-president-xi-jinping-now-has-a-dozentitles-and-counting/, (27.5.2018). 
As the head of state, this offers Xi a free hand to focus on fortifying his leadership and also the party's authority without letting anyone hamper the development of both. By appointing Wang Qishan - a retired Politburo Standing Committee member - as the new Vice President of China, and also removing the two-term limit for the Vice-President, Xi has allowed Wang to conduct presidential responsibilities on his behalf. ${ }^{21}$ Wang, also known as Xi's "American hand", owing to his vast knowledge and experience in dealing with the US's politics and economy, has been constantly with $\mathrm{Xi}$ in his anti-corruption drive. ${ }^{22} \mathrm{As}$ for the role of the vice president, according to Article 82 of China's constitution ${ }^{23}$ :

The Vice-President of the People's Republic of China assists the President in his work.

The Vice-President of the People's Republic of China may exercise such functions and powers of the President as the President may entrust to him.

Although the role of the Vice President is usually ceremonial, Wang yields more power and influence than his predecessors. Xi too appears determined to empower him, especially in his anti-corruption drive and foreign policy dealings.

Another shot at power consolidation is the setting up of the new National Supervision Commission (NSC) - an important domestic administrative anticorruption agency which will merge all important elements of the Communist Party, government, judiciary and police into one powerful agency. It is China's latest discipline-enforcement body ranked with the central government, which will work closely with courts to interrogate and detain not only members of the CCP but also corrupt officials of various state-owned enterprises, municipal and village bodies and educational, sports and cultural institutions. ${ }^{24}$ Such intense consolidation of decision-making power is seen with caution, as the Party Politburo's Standing Committee as well as all the other leaders of provinces are of President Xi's choosing. However, notwithstanding the claims that a robust all-encompassing Supervision Commission will strengthen China's rule of law, it might actually be detrimental and make the system vulnerable to political manipulation.

Moreover, such centralisation of power in one individual is the antithesis of what Deng Xiaoping did in the 1980s to make the governance system more systematic. He had set in place a new mechanisms, which included the

\footnotetext{
21 "Wang Qishan Elected Vice-President of China", Xinhuanet, 3/2018, http://www. xinhuanet.com/english/2018-03/17/c_137045280.htm, (27.5.2018).

22 "Wang Qichan returns as Vice President", China Digital Times, 3/2018, https:// chinadigitaltimes.net/2018/03/wang-qishan-returns-as-vice-president/, (27.5.2018).

23 "Constitution of the People's Republic of China" The State Council PRC, http://www.npc. gov.cn/englishnpc/Constitution/2007-11/15/content_1372966.htm, (27.5.2018).

24 Gueorguiev Dimitar, Stromseth Jonathan: "New Chinese agency could undercut other anti-corruption efforts", Brookings, 3/2018, https://www.brookings.edu/blog/order-fromchaos/2018/03/06/new-chinese-agency-could-undercut-other-anti-corruption-efforts/, (27.5.2018).
} 
reinstitution of the posts of President and Vice-President but with a term limit of two years and mandatory retirement ages. This was to prevent over-concentration of power and one-man shows from happening again like in Mao's era. ${ }^{25}$ Having "collective leadership" was more important. By breaking this pattern, Xi has now created doubt and insecurity in the minds of many, making them reminisce China's old days of personality cults and chaotic domestic politics.

According to many experts however, these amendments are necessary considering the domestic shifts China is undergoing. Its economy is under stress, experiencing a growth rate of about 6.7 in 2016, which is now called the "new normal". It was the lowest rate since $1990 .{ }^{26}$ Moreover, achieving a high growth rate is important to push Xi's flagship - BRI - forward. Currently, it requires long-term planning and utmost engagement with international bodies. Under these circumstances, it is crucial to have a stable, forward-thinking leadership. Besides, even the anti-corruption drive needs a long-term action plan which only a strong leadership under Xi can implement.

When scrutinised, the government restructuring that China is undergoing now is the biggest since Zhu Rongji, a former Premier who initiated the liberalising economic reforms in the 1990s. ${ }^{27}$ The current government reorganisation involved creating seven new ministries - ecological environment; natural resources; emergency management; agriculture and rural affairs; culture and tourism; veterans affairs; and the National Health Commission. ${ }^{28}$ China's different administrative controls have been tightened and constricted under special centrally operating agencies. For instance, the banking and insurance agencies have been merged and special central agencies have been formed to manage immigration issues and those of military veterans. ${ }^{29}$ While these administrative changes are meant to streamline the work done by the different ministries and improve their efficiency and ensure accountability, there are

25 Yan Jun: "Reported in Decrypting the 1982 Constitution: Abolishing the Tenure of Leading Officials", PLA Daily Client, 12/2014, http://www.81.cn/jsdj/2014-12/03/ content_6253829_2.htm, (27.5.2018); Zhifei Wu:"Deng Xiaoping: My last role is to take the lead in establishing a retirement system", People's Daily-CCP news, 8/2014, http://dangshi. people.com.cn/n/2014/0812/c85037-25452561.html(27.5.2018).

26 Allen Katie: "Chinese Growth Slips to Slowest Pace for 26 Years", The Guardian, 1/2017, https://www.theguardian.com/business/2017/jan/20/chinese-economicgrowth ..., (27.5.2018).

27 Kui-wai Li (2001): "The Two Decades of Chinese Economic Reform compared", APEC Study Centre City, University of Hong Kong, China and World Economy, No. 2.

28 Zhang Shu, Lee Se Young; "China to merge regulators, create new ministries in biggest overhaul in years", Reuters, 3/ 2018, https://www.reuters.com/article/us-chinaparliament/china-to-merge-regulators-create-new-ministries-in-biggest-overhaul-inyears-idUSKCN1GP003, (27.5.2018); "An overhaul of China's bureaucracy enhances the party's authority", The Economist, 3/ 2018, https://www.economist.com/china/2018/03/15/ an-overhaul-of-chinas-bureaucracy-enhances-the-partys-authority, (27.5.2018).

29 Ibid. 
opposing views which find such tightening of governmental administrative bodies to be draconian.

However, it would be unfair to argue that these changes have not been long cherished. The pitfalls of the Chinese economy and polity were lamented by the previous leaders as well. For Wen Jiabao in 2007, China was characterised by "four "uns" - unbalanced, unstable, uncoordinated and unsustainable. ${ }^{30}$ His successor, Li Keqiang, shared similar thoughts. Until now, maintaining the economy and other domestic issues were overseen by the Premier and Leading Small Groups (LSGs). But since the Third Plenum in 2013, the economy has come a lot under Xi Jinping's radar, who from time to time has been recorded arguing that only massive reforms and developmental changes can help China become a superpower by $2049 .^{31}$

\section{Historical Underpinning}

According to political pundits, the likely course China will take in the future will depend on the developmental path Xi Jinping undertakes. A very clear delineation is given by David Shambaugh in his book China's Future. ${ }^{32}$ Shambaugh projects four possible trajectories for China -hard authoritarianism, neototalitarianism, soft authoritarianism and semi-democracy. Since Xi Jinping entered office, he argues, China has been adopting policies seen as more and more authoritarian. Shambaugh contends that such concentration of power suggests weak internal dynamics, which is bound to stagnate China's economic progress and lead to acute social discomforts.

In the past, China's other leaders had time and again emphasised on China attaining the status of a great power but within a more democratic setting. $\mathrm{Hu}$ Jintao, for example, said that the Chinese people were to become the "masters of the country" with the right "to be informed, to participate, to be heard, and to oversee". ${ }^{33}$ In this regard, even the CPC would not be spared from scrutiny of its decision-making and exercise of power. Likewise, the then Premier Wen Jiabao, in a meeting at the Brookings Institution in Beijing in 2006, discussed the significance of democracy, arguing that "democracy is a universal value that

\footnotetext{
30 "China Confident in Maintaining Economic Growth: Premier", Xinhua News Agency, 3/2007, http://www.china.org.cn/english/2007lh/203252.htm, (27.5.2018).

31 "Decision of the Chinese Communist Party Central Committee on Several Major Questions about Deepening Reform", Third Plenary Session of the 18th Central Committee of the CPC , 11/ 2013, http://www.china.org.cn/china/third_plenary_session/2014-01/16/ content_31212602.htm, (27.5.2018).

32 Shambaugh David (2016) :China's Future, Malden, MA: Polity Press, UK, 2-6.

33 Fook Liang Lye (2008): "China's Measured Media Liberalization: Gearing up for the Beijing Olympics”, EAI Background brief no. 392.
} 
includes the three important components: elections, judicial independence, and supervision based on checks and balances".

Until 2009, CCP was known amongst foreign policy analysts to be following a system of "resilient authoritarianism" which involved loosening of political controls and reforming the political institutions, especially during the last four years of Jiang Zemin's tenure and in Hu Jintao's first six years in office. ${ }^{34}$ Such reforms were characterised by "consultative democracy" 35 and "multiparty cooperation", ${ }^{36}$ which implied that party consultation was expanded to include non-party elements such as civil society and intellectuals. Retirement ages and term limits were enforced on the leaders. To forestall collapse like that of the Soviet Union, the CCP thought it was absolutely necessary to liberalise Chinese political reforms as a softer form of authoritarianism. ${ }^{37}$

However, quivering the pitch were the riots in Lhasa in 2008 and Urumqi in 2009. The unnerved party tightened the political security apparatus. Bureaucracies consolidated their power, and according to Shambaugh they coalesced into an "Iron Quadrangle" comprising the party propaganda apparatus, the state-owned-enterprise sector, internal security organ (the Ministry of State and Public Security) and the People's Liberation Army (PLA) forces. They not only reversed all the previous political reforms, but also tightened party control and security, using $\mathrm{Hu}$ Jintao as a susceptible puppet, manipulating him to gain massive financial gains as well.

In 2012, with the 18th Party Congress, a new leadership led by Xi Jinping signalled the coming of more systematic planning. It became even clearer in the Third Plenum held in November 2013 that Xi was going to change the functioning of China's economic foundation, with the communique titled "Decision on Major Issues Concerning Comprehensively Deepening Reforms". ${ }^{38}$

But in the third quarter of 2012 when real GDP growth fell to 7.4 per cent - the seventh consecutive quarter of falling growth ${ }^{39}$ - again to be followed

\section{$34 \quad$ Ibid.}

35 "Consultative democracy" was first included in political reforms in China in 2012 in a report given by President Hu Jintao at the 18th CPC National Congress. CPPCC is China's main platform for consultative democracy, and involves representatives from CPC and nonCPC parties, those without any affiliation, civil societies and ethnic minorities, fn1.

$36 \mathrm{CPC}$ is the main party exercising political leadership on a political ideology and policy decisions but there are other parties, subject to CPC's leadership. A consensus on socialism with Chinese characteristics is the foundation of this multi-party cooperation system, fn2.

37 Shambaugh David, 8.

38 "The Decision on Major Issues Concerning Comprehensively Deepening Reforms in brief", Third Plenary Session of the 18th Central Committee of the CPC 11/2013, http:// www.china.org.cn/china/third_plenary_session/2013-11/16/content_30620736.htm, (27.5.2018).

39 "Economic and Monitory Developments - The external environment of the euro area", ECB Monthly Bulletin,1/2013, 11-12. 
by a downfall of 6.9 percent and 6.6 per cent in 2015 and 2016 respectively - a 25 -year low - the government itself lowered its annual target growth rate to a "normal 6.5 percent" for the next five years. ${ }^{40}$ So, this new juncture that China is at, with hardened political reforms and an unstable economy, is being looked at as destabilising the Xi regime by many political scientists. In 2006, Minxin Pei described China's economic condition as a "trapped transition", where it is constrained by the repressive political structure as a superstructure. Ian Bremmer predicted that even though China has embraced globalisation to some extent, lack of transparency in government functioning is bound to make the economy, and concomitantly the regime, unstable. ${ }^{41}$ Zbigniew Brzezinski in The Grand Failure (1989) also makes akin arguments, though in the context of the Soviet Union. A moribund economy when combined with a political system marked by deep-seated insecurity, only leads to more hollowing out of power, control and mobilisation of the regime.

What is surprising is that Xi's consolidation of unrestricted power has become emblematic of not just his supremacy, but also his perceived fragility. ${ }^{42}$ In the process of making himself the most powerful in China since Mao, he has earned himself a significant number of enemies. $\mathrm{Xi}$ is aware that his power stays as long as he wields the apparatus of the state and the party. Consequently, he has ruthlessly eliminated any group or individual that could pose a threat to his authority. He has jailed and purged numerous generals and tycoons on corruption charges, belonging even to the powerful PLA. ${ }^{43}$ His approach is based on the guiding themes of controlled and fervent nationalism, focusing on the state being in control of everyday public lives.

If not deftly managed, such intense consolidation can become risky for $\mathrm{Xi}$. Targeting the elites or purging them incessantly will undermine the elite support and weaken Xi's support within the elite groupings. This might motivate rival domestic groups or competitors to fortify their stance against Xi. Though this seems far-fetched, a string of policy failures can very well destabilise the current regime. ${ }^{44}$ Moreover, to realize the "Chinese Dream" today, China must tackle

$40 \quad$ Yao Y. (2014):“A New Normal, but with Robust Growth: China's Growth Prospects in the Next 10 Years", 77-82.

$41 \quad$ Bremmer Ian, “China's rising influence 'inevitable" ”, CCTN, 11/ 2017, https://news.cgtn. com/news/7863444d35597a6333566d54/share_p.html, (27.5.2018).

42 Svolik Milan (2009), "Power Sharing and Leadership Dynamics in Authoritarian Regimes," American Journal of Political Science 53, no. 2, 477-494.

43 Chellaney Brahma, “Xi’s new strength obscures China’s internal risks”, 10/2017, The Japan Times, https://www.japantimes.co.jp/opinion/2017/10/29/commentary/world-commentary/xis-new-strength-obscures-chinas-internal-risks/, (27.5.2018).

44 Pikner Stephan: “Fewer Checks, More Balancing: How Xi Jinping's Consolidation of Power Changes the Risk of War", The Bridge, 3/2018, https://www.realcleardefense.com/ articles/2018/03/29/fewer_checks_more_balancing_how_xi_jinpings_consolidation_of_ power_changes_the_risk_of_war_113257.html, (27.5.2018). 
a number of critical issues like environmental pollution, poverty, corruption, abuses of power, demographic imbalance, food safety and energy consumption inefficiency among others. While Xi has demonstrated good accountability and a better appetite for risk-taking, domestic turmoil resulting from such problems could raise the stakes for him. Considered together, Xi's centralization of power and elimination of rivals is moving the CCP regime towards a situation, which in its generic form, is prone to instability. That is all the more reason why China needs to have a stable neighbourhood and maintain the regional balance of power while rapidly modernising its PLA. Other Asian democracies like Taiwan, Japan, South Korea and India are not taking well to China using instruments of coercive diplomacy while also breaching international rules to secure its interest in the region.

\section{Juggernauting Foreign Policy}

Just as Deng Xiaoping had steered China's economic rise in the 1970s and made its presence felt globally, ${ }^{45} \mathrm{Xi}$ too is striving relentlessly through an assertive foreign policy to raise China's stature in international geopolitics. ${ }^{46}$ Most recently, through BRI, the grandest strategy so far, China has launched colossal infrastructure programmes worth trillions of dollars to improve connectivity, trade and investment between Asia, Africa and Europe. ${ }^{47}$ While over 70 countries have agreed to partake in the various developments, there are several nuances that have to be taken care of, such as building basic infrastructure in the poorly connected regions of Asia and Africa, attracting global investors to participate, ensuring large-scale participation from emerging markets, capitalising on those markets while taking care of environmental concerns and, most importantly, ensuring that China does not end up hegemonising the smaller powers. ${ }^{48} \mathrm{Xi}$ has

$45 \quad$ Chow G.C (2004): "Economic reform and growth in China. Annals of Economics and Finance", 152; "From Deng to Xi - Economic reform, the Silk Road and the return of the Middle Kingdom, Special Report”, LSE Ideas, 5/ 2017; Morrison W.M. (2013): “China's Economic Rise: History, trends, challenges, and implications for the United States", Library of Congress, Congressional Research Service, 2-37.

46 J.A. Bader: "How Xi Jinping Sees the World ... and Why", Asia Working Group, Foreign Policy, Brookings, 2/2016; Zhang Jian (2015): “China's New Foreign Policy under Xi Jinping: Towards 'Peaceful Rise 2.0'?”, Global Change, Peace \& Security, 1, 5-19; Hass R. et al. (2017): "The Trajectory of Chinese Foreign Policy: From reactive assertiveness to opportunistic activism", Center for East Asia Policy Studies, Brookings Institute.

47 Miller Tom (2017): China's Asian Dream: Empire Building along the New Silk Road, Zed Books, London, 5-9.

48 Cai Pete (2017): “Understanding China's Belt and Road Initiative”, Lowy Institute for International Policy, https://www.lowyinstitute.org/sites/default/files/documents/ Understanding\%20China\%E2\%80\%99s\%20Belt\%20and\%20Road\%20Initiative_WEB_1. pdf, (27.5.2018). 
already revealed China's hegemonic goals of becoming a global superpower and a modern socialist industrial state by the time it is the centenary of China, i.e. $2049 .{ }^{49}$ For such grandiose goals to bear fruit it is important to lay a strong and resilient foundation now. An unlimited term limit hence gives President Xi more elbow room and continuity to manoeuvre in materialising his economic and political reforms.

This visualisation also includes upgrading China's military and defence capabilities for it to become an indestructible fighting force by 2035. Massive defence outlays are being initiated by various means like expansion of naval bases, investments in strategic ports, development of cutting-edge technologies, cooperation with likeminded countries, etc. In fact, as informed by the state media, China is going to spend US $\$ 175$ billion across all the divisions of the PLA. The military spending got incremented by 8 percent this year compared to 7 percent in 2017. However, if one sees China's aspirations of satiating its 'China dream', one will realise that having a 'strong military dream' is a very crucial component of that dream. President Xi's grand strategy of making 'China great again' too is intrinsically connected to that yearning. China already has the world's second-largest military budget, largest navy and maritime militia, and is experiencing the fastest and biggest shipbuilding expansion..$^{50}$ Undoubtedly, all of this is buttressing its profile as a great power and establishing popular support domestically, especially amongst those sections fervent about national rejuvenation and restoring China's historical statute.

Not just in the military sphere, China has cast its pre-eminence worldwide. It has extended its definition of "core interests" to even include the South China Sea and has asserted sovereignty rights over it, contrary to international law, i.e. United Nations Convention on the Law of the Sea (UNCLOS). ${ }^{51}$ China has always rejected, or rather challenged, the idea of a Western model of growth and development, western values like the idea of democracy being most suitable for

49 Callahan William (2016): "China 2035: from the China Dream to the World Dream”, Global Affairs, 2:3, 247-258.

50 “China Modernizing Military by Increasing Spending by 8 Percent”, Special Operations, 3/2018, http://specialoperations.com/32630/china-modernizing-military-increasingspending-8-percent/, (27.5.2018).; "China boosts military spending 8\% amidst ambitious modernization drive", $C N N 3 / 2018$, https://edition.cnn.com/2018/03/04/asia/chinese-military-budget-intl/index.html(27.5.2018); "China boosts defense budget in quest for 'world class' military but tells neighbors not to worry", The Washington Post, 3/ 2018, https:/www.washingtonpost.com/world/asia_pacific/china-boosts-defense-budget-seeking-world-class-military-but-tells-neighbors-not-to-worry/2018/03/05/17a27efb2a9d-4508-a06e-f3129bdlea45_story.html?noredirect=on\&utm_term=.aae5259ed0ca, (27.5.2018).

51 T. James: “The South China Sea Dispute: China's Polygonal Defence of Core Interests", RUSI, 7/2016, https://rusi.org/commentary/south-china-sea-dispute-chinas-polygonal-defencecore-interests, (27.5.2018); "Chinese South China Sea Claims" Global Securityhttps://www. globalsecurity.org/military/world/china/south-china-sea.htm, (27.5.2018). 
economic progress. For instance, by creating an alternative global governance structure through cooperative mechanisms like BRICS (Brazil, Russia, India, China and South Africa), the Asian Development Bank (ADB) and the Shanghai Cooperation Organisation (SCO), China is seeking to have a far-reaching bearing on the liberal global order previously led by the West. ${ }^{52}$

In fact, China has gone as far as to set up firewalls to control its internet and prevent Chinese citizens from getting exposed to western ideas. However, this is where China lags. By controlling the media, it manifests a certain level of vulnerability and coyness. The general perception around the world is that not much has changed in China since Mao Zedong's time, who created selfdestructing policies, which resulted in mayhem and led to thousands of deaths. His authoritarian regime had cost China heavily. Though Xi is exercising his power prudently and recent developments suggest that under his rule China cannot be considered as a traditional totalitarian state, his assertive foreign policies and bold domestic reforms are spewing much concern.

When it comes to asserting China's foreign policy, $\mathrm{Xi}$ is coalescing "bringing-in" and "going-out" initiatives, actively pursuing it through these foreign policy propositions:

- "a new type of major-power relationships";

- "major-country diplomacy with Chinese characteristics";

- "a community of common destiny";

- "a new type of international relations".

All of these propositions have different connotations when engaging with countries across the world - juxtaposed between win-win cooperation and zerosum rivalry. The main strategic ambition however is twofold: (a) As a staunch advocate of economic globalisation, China seeks to enhance its position as a global leader equal at par with the US; and (b) China wants to lead international affairs by pursuing shared benefits through collaboration and consultation between various countries and organizations, particularly focusing on Asia-Pacific.

Sino-US relations figure broadly in China's proposition of this "new type of major-power relations". ${ }^{53}$ As Wang Qishan, the most experienced politician on the US, is already positioned as Xi's right hand, Xi foreign administrative strategy will without doubt be more US-centric than before. ${ }^{54}$ China views

$52 \quad$ Haibin Niu (2013): "BRICS in Global Governance a Progressive and Cooperative Force?" Friedrich Ebert Stiftung, 9/2013; Rewizorski M. (2015):“The European Union and the BRICS: Complex Relations in the Era of Global Governance, 1-180.

53 Lampton David: "A New Type of Major-power Relationship: Seeking a Durable Foundation for U.S.-China Ties”, China \& US Focus, 9/ 2013, https://www.chinausfocus.com/foreign-policy/a-new-type-of-major-power-re..., (27.5.2018).

54 Mitchell Tom: "Xi Jinping Ally Wang Qishan Confirmed as New China VicePresident", Financial Times, 3/2018, https://www.ft.com/content/aa260008-28d311e8-b27e-cc62a39d57a0, (27.5.2018). 
President Donald Trump's retreating from the TPP - the Asia-Pacific multilateral trade grouping - as a strategic opportunity to spread its influence all across Asia. Whether it is in South Asia, Southeast Asia or East Asia, China's key foreign policy goal as stated by the government is to ensure regional stability, fostering the principles of good state-to-state relations in international relations through mutual respect, win-win cooperation and promoting fairness and justice.

Committed to the "bringing-in" initiative, $\mathrm{Xi}$ has so far hosted a number of seminars and conferences ranging from the May 2014 Conference on Interaction and Confidence Building Measures in Asia (CICA), the November 2014 AsiaPacific Economic Cooperation (APEC) summit, September 2016 Group of Twenty (G20) summit, the May 2017 BRI forum, the September 2017 BRICS summit, the Shanghai Cooperation Organisation (SCO) summit etc. Likewise, for his "going-out" campaign, Xi has travelled extensively to over fifty countries in his first term, paid visits to the headquarters of different regional and global organisations and has delivered multiple speeches overseas. For the BRI, China has engaged in interactions with 16 Central and Eastern European Countries (CEEC), signing Memorandum of Understanding with most of them to work on priority areas of cooperation like trade and investment, logistics, financial and technological cooperation and promoting tourism, sport and culture.

Thus, it can be seen that China is extending its interests and influence much beyond Asia-Pacific to Europe and Africa as well. Strengthening bilateral and multilateral links, enhancing maritime security, pursuing economic cooperation through free trade agreements (FTAs) in addition to consolidating regional integration and connectivity are some of the key features of China's foreign policy outreach. It has been highlighted well in the January 2017 Chinese White Paper, titled China's Policies on Asia-Pacific Security. ${ }^{55}$ To secure his grand Asia-Pacific propositions, Xi has intensified work on the New Development Bank (NDB) under BRICS, the Asian Infrastructure Investment Bank (AIIB) and the new Silk Road Fund (SRF) under BRI. Pointed out by Trump to be revisionist in nature, these initiatives definitely reflect the changing nature of the status quo of the landscape through rapid infrastructure developments and effectual trading strategies. ${ }^{56}$

It is certain that China does not trust the US, India, Australia and Japan forming the Quadrilateral initiative. It might in fact buttress China's attention more on the Asia-Pacific. Moreover, Trump's vague Asia policy does not provide any assurance to the smaller countries, thus egging them to hold on to China's

55 China's Policies on Asia-Pacific Security Cooperation, State Council Information Office of the People's Republic of China, 1/2017, http://www.xinhuanet.com/ english/2017-01/11/c_135974121.htm, (27.5.2018).

56 National Security Strategy of the United States of America, White House, 12/2017, https://www.whitehouse.gov/wp-content/uploads/2017/12/NSS-Final-12-18-20..., (27.5.2018). 
support and use it as an opportunity. ${ }^{57}$ South Asian countries as well are drawn towards China's initiatives there, often known as China's “infrastructure-led investment policy". ${ }^{8}$ Through Special Economic Zones (SEZs) and the US\$57 billion China-Pakistan Economic Corridor China is tilting more towards the Central and Middle Eastern markets. ${ }^{59}$

Lastly, the coming years will see Xi intensifying the stature of BRI across the world, marked by Beijing signing multilateral and bilateral deals, boosting connectivity through economic corridors and forging stronger political contacts. It will not only provide an impetus to China's economic development but also address issues of poverty, economic inequality etc. ${ }^{60}$ However, it is certain that testing times are arriving for immediate neighbours like India who are not completely in sync with China's connectivity projects.

\section{India Playing Catch-up}

With Xi Jinping assiduously assuring his tenure while incorporating all the said "lost territories" of China, it has become quite understandable that there is no stopping China from pursuing expansionist activities. ${ }^{61}$ In essence, since he has come to power, China has assertively begun to secure territories in its periphery, be it the East China Sea, South China Sea or strategic ports in the Indian Ocean. Such incremental acts of territorial occupation are now being commonly referred to as China's grand strategy of salami slicing. ${ }^{6263}$ China has in fact succeeded in conducting stealth military operations which when accumulated over time can actually result in large territorial gains from neighbouring territories. For

57 Loh Dylan: “How Xi Jinping's 'Lifetime Presidency' Could Change China - For Better or Worse", The Conversation, 2/ 2018, http://theconversation.com/how-xi-jinpings-lifetime-presidency-could-cha.., (27.5.2018).

58 Hashmi Rehana: “China's ambitions abroad : The case of South Asia” IAPS Dialogue, 2/2018, https://iapsdialogue.org/2018/02/15/chinas-ambitions-abroad-the-case-of-thesouth-asian-region/, (27.5.2018).

59 Pant V. Harsh.:"China's clout grows in South Asia, but can India raise its game?" South China Morning Post, 1/ 2018, http://www.scmp.com/comment/insight-opinion/ article/2129480/chinas-clout-grows-south-asia-can-india-raise-its-game, (27.5.2018).

60 Full text of President Xi's speech at opening of Belt and Road forum, 5/2017, http://www. xinhuanet.com/english/2017-05/14/c_136282982.htm, (27.5.2018).

${ }_{61}$ Fravel M. Taylor (2010): “International Relations Theory and China's Rise: Assessing China's Potential for Territorial Expansion”, International Studies Review, 12, 505-532

62 Miller Tom (2017):China's Asian Dream: Empire Building along the New Silk Road, Zed Books, London, 41.

63 It involves subtle piece-by-piece expansionism, where every new piece of occupation is not momentous enough to ignite a war but when considered together after a period of time is momentous enough to radically alter the balance of power, fn3. 
instance even in the South China Sea, China's position is much tougher than it was a decade ago. ${ }^{64}$

China's approach with India has more or less been the same in the past decade. Most recently, apart from the Doklam standoff between the two countries, there has been no dramatic difference in the way $\mathrm{Xi}$ or the previous leaders in China dealt with India. They have always shown the same proclivity in maintaining harmonious relations with India, at least on paper. During Deng Xiaoping's time, China was pursuing an "open-door" policy and relations with India were rather modest, normalised more when then Indian Foreign Minister A.B. Vajpayee's visited China in 1979 and then Prime Minister Rajiv Gandhi's visited it in $1988 .{ }^{65}$ China under Jiang Zemin and Hu Jintao pursued "greater conservatism" where it was focusing majorly on domestic economic growth while keeping a low profile in the international scene. ${ }^{66}$ China and India were also engaging in various confidence-building measures (CBMs) in 1993 and 1996 to thrust their then passive relationship forward. This got more institutionalised during $\mathrm{Hu}$ Jintao's leadership, with the signing of multiple agreements and memorandums of understanding (MoUs).

However, with $\mathrm{Xi}$ in power, strategists are claiming that China is expanding its claims on the Indian territory by making use of the poor infrastructure in border areas and the inability of the Indian armed forces to be stationed in every nook. ${ }^{67}$ The connectivity of these bordering areas to the rest of the country is also deplorable. For instance, China is targeting some of the most strategic but difficult terrains of India, such as in the volatile regions of Ladakh's Despang and Chumar areas. ${ }^{68}$ The encroachment in the state of Arunachal Pradesh and more recently in a tri-junction in Bhutan which gives direct access to India is a grave threat through India's Chicken Neck, the narrow Siliguri corridor. ${ }^{69}$

Now with Xi continuing his term, there are three options for India - it can mend its frosty ties with China, accede to their demands and get into their good books, it can pursue an antagonistic foreign policy and club with other major powers against China, or pursue a diplomatic and 'smart' foreign policy which while aligning with major powers also heeds China's sensitivities. The present

$64 \quad$ Zhang Feng (2017): "Chinese Thinking on the South China Sea and the Future of Regional Security”, Political Science Quarterly, 132:3.

65 Gonsalves Eric: “The India-China Parleys (1979-1982)”, Indian Foreign Affairs Journal, 10-12/2013.

66 Lanteigne Marc (2009): “Who Makes Chinese Foreign Policy Today?", Chinese Foreign Policy: An Introduction, Routledge, London,19.

67 Goswami Namrata (2012): “China's Territorial Claim on Arunachal Pradesh”, IDSA Occasional Paper no. 29.

68 Chellaney Brahma: "China's Game Plan to Keep India on the Back Foot", Livemint, 7/2013, https://www.livemint.com/Opinion/RQ477pBeAEWGgsbmQ2FaCL/New-Delhiand-Chinas-game-plan.html, (27.5.2018).

69 Goswami Namrata, 15. 
Indian Government seems to be pursuing the third option. Bigger risks exist for India now, with China lashing out strong headwinds if it feels its 'core interests' are at stake. ${ }^{70}$

China has already improved military relations with Russia, India's oldest friend, and even made it a big player in the BRI, along with several other countries in India's neighbourhood. The trade deals China is seeking to secure with them is bound to lure them all into China's orbit. The United States too is no longer reliant on West Asia for oil, thus opening the road for China to be India's major competitor for these resources.

There are talks among Chinese officials of something called "oriental wisdom", mostly involving using the Five Principles of Peaceful Coexistence within the ambit of Panchsheel to settle political differences. ${ }^{71}$ This essentially requires 'political' understanding between the two countries at the highest political level. So, for now there are only dialogues taking place between the Special Representatives (SR) through boundary dispute negotiations, Disputed Areas Dialogue Group and Border Movement Management and Monitoring Group.

Yang Jiechi, the Chinese interlocutor for the SRs dialogue, was promoted to state council or at the 19th National Congress. ${ }^{72}$ As both Wang Yi and Yang Jiechi - two important officials in current Chinese political system - have rich experience in dealing with Asian affairs, ${ }^{73}$ better cooperation and dispute settlement should be facilitated, despite unequal Gross Domestic Product (GDP) and asymmetrical military capabilities between the two countries.

Economic interdependence has usually been the pacifying effect on politically adversarial states. While India is more dependent on China than China is on India, both the countries' economies are export-driven. Being the largest countries in the region they cannot afford to ignore each other's presence, notably more because of the apprehensions of what the other power might do with any of their other rivals. What is required now is a 'smart-balancing' act

$70 \quad$ Swaine Michael D., “ China's Assertive Behavior Part One: On “Core Interests””, China Leadership Monitor, no. 34.

71 "Interview with Chinese Ambassador Le Yucheng by PT", News from China, 9/2014, 20-21; "Full Text of Li Keqiang's Speech at Opening Ceremony of Boao Forum", Ministry of Commerce, People's Republic of China, 4/2014, http://english.mofcom. gov.cn/article/zt_boaoforum2014/news/201404/201404..., (27.5.2018).

72 The National People's Congress of the PRC, http://www.npc.gov.cn/englishnpc/news/ Appointments/node_2765.htm, (27.5.2018).

73 "Yang Jiechi, border negotiator with India, promoted to elite CPC body", The Times of India, 10/ 2017, https://timesofindia.indiatimes.com/world/china/yang-border-negotiator-with-india-promoted-to-elite-cpc-body/articleshow/61229050.cms, (27.5.2018).; "Meet the team China expects to unknot ties with the United States", South China Morning Post, 3/2018, http://www.scmp.com/news/china/diplomacy-defence/article/2137922/meetteam-china-expects-unknot-ties-united-states, (27.5.2018). 
with China. ${ }^{74}$ Only informal meetings cannot be the ultimate barometer of measuring the effectiveness of having an active foreign policy. Especially for India in the face of an unpredictable Donald Trump, an insecure Japan and weak South Asian countries, not mending ties fast with China might constrict its diplomatic manoeuvres.

It is important for both India and China to reduce the tension points domestically and abroad. It is high time the relationship moves on from gunboat diplomacy to 'yacht diplomacy', implying a more relaxed and cooperative form of foreign policy manoeuvring which is not completely based on the principles of realism. ${ }^{75}$ There is a larger context to India's relationship with China and that should not be wasted in vain. Although the relationship now is very personality driven - considering the hold Xi has on China and the temper President Narendra Modi has set for India - there is also a need to secure proper institutional backing. ${ }^{76}$ The current bonhomie might not last long in the face of asymmetrical power capabilities, creating more space for confrontation than peace. Moreover, it is important for both countries to represent popular aspirations if long term goals are to be met. Settling frictions only based on the strong personalities representing the countries and the political ideologies they hold cannot suffice for good India-China relations.

Additionally, in order to bridge the gap between holding meetings and implementing policies, the backing of formal institutions is crucial. When it comes to India and China especially, meetings have not been able to be translated into concrete policies owing to several factors like political contentions, ego clashes, non-disclosure of information, deferred decisions etc. Therefore the onus should be more on settling the trust deficit between them as lately it has escalated due to an 'information deficit' as well. ${ }^{77}$ Boosting mid-level political talks besides cultural exchanges and scholarly meets can prove beneficial.

Thus, Xi Jinping's extended leadership should be seen strategically, to manoeuvre enough elbow room to upgrade India-China relations. Abiding by the "developmental partnership" envisioned between the two countries during

$74 \quad$ Jacob Happymon: “Smart-balancing China”, The Hindu, 11/ 2017, http://www.thehindu. com/todays-paper/tp-opinion/smart-balancing-china/article20946375.ece, (27.5.2018).

75 “China says it wants to stick to 'right path' of bilateral ties with India, explore new areas for cooperation", First Post, 5/2018, https://www.firstpost.com/world/china-says-itwants-to-stick-to-right-path-of-bilateral-ties-with-india-explore-new-areas-for-cooperation-4434095.html,, (27.5.2018).

76 Thakker Aman: "Beyond Wuhan: India Should Establish A New Framework for Engagement With China" The Diplomat, 5/2018, https://thediplomat.com/2018/05/ beyond-wuhan-india-should-establish-a-new-framework-for-engagement-with-china/, (27.5.2018).

77 “Trust deficit led to Doklam standoff; Modi \& Xi to bridge that gap", The Times of India, 4/2018, https://timesofindia.indiatimes.com/india/trust-deficit-led-to-doklam-standoffmodi-xi-to-bridge-that-gap/articleshow/63902989.cms, (27.5.2018). 
Xi's visit to India in $2014^{78}$ is consequential if close economic and political contacts are to be sustained. Post-Doklam, during the BRICS summit and the recent "informal" meet in Wuhan, China, Modi and Xi Jinping have articulated a stronger interest in pursuing a "forward looking constructive" relationship to further nurture their developmental partnership. ${ }^{79}$ This forward thinking orientation of the two leaders should not be taken for granted, but translated into more meaningful engagements.

\section{Conclusion}

Xi's extension of power as the President of China implies a strong, institutionalised authoritarian regime having the full backing of the CPC and the PLA. The constitutional amendment bringing this forth provides a vital window into the working of Chinese domestic politics, offering a ground for a game of musical chairs - deciding who leaves and who stays. Additionally, to understand China's emerging precedence in global politics, it is important to juxtapose Beijing's bilateral and multilateral ties. Such precedence has several insinuations for neighbouring middle powers like India, Japan and South Korea. While China is securing stronger bilateral ties with them, multilaterally too there are testimonies of growing partnerships, especially through the Belt and Road Initiative. However, according to political pundits, the reason why $\mathrm{Xi}$ is pursuing such an active foreign policy is because he has to obscure China's internal risks in the face of domestic upheavals. Avoiding a political hard landing is important for Xi, especially after securing an unlimited term for himself.

It goes without saying that Beijing's foreign affairs have consequential bearing on its neighbouring powers. This is precisely why India should be well prepared to see more of China and Xi Jinping's influence in its foreign policies - economically, politically and militarily. India also needs to win back its old friends like Russia in the neighbourhood by timely implementation of existing agreements and proactively working towards newer areas of interest. However, when it comes to settling boundary disputes between India and China, continuity of Xi's leadership should not be treated negatively in its entirety. A change of China's government might have also changed its current foreign policy posture of strongly seeking to settle disputes. India should view this prudently and form a well-balanced outlook towards amending bilateral ties. It does not have to necessarily take place at the highest political level or at the bureaucratic level only, but

\footnotetext{
78 Joint Statement between the Republic of India and the People's Republic of China on Building a Closer Developmental Partnership, Ministry of External Affairs (MEA), 9/ 2014

79 India-China Informal Summit at Wuhan, MEA, 4/2018, http://www.mea.gov.in/press-releases. htm?dtl/29853/IndiaChina+Informal+Summit+at+Wuhan(27.5.2018).
} 
can be opened to interactions between young scholars, businessmen, cultural enthusiasts etc.

\section{Literature}

- Cai Pete (2017): “Understanding China’s Belt and Road Initiative”, Lowy Institute for International Policy.

- Callahan William (2016): "China 2035: from the China Dream to the World Dream”, Global Affairs, 2:3, 247-258.

- Chow G.C (2004): "Economic reform and growth in China. Annals of Economics and Finance", 152.

- Fook Liang Lye (2008): "China's Measured Media Liberalization: Gearing up for the Beijing Olympics", EAI Background brief no. 392.

- Fravel M. Taylor (2010): "International Relations Theory and China's Rise: Assessing China's Potential for Territorial Expansion”, International Studies Review, 12, 505-532.

- Friedrich Carl J, Brzezinski, Zbigniew K. (1956): Totalitarian Dictatorship and Autocracy, New York, 367-368.

- Ginsburg Tom, Simpser Alberto (2014): "Introduction, Chapter 1 of Constitutions in Authoritarian Regimes", University of Chicago Public Law \& Legal Theory Working Paper No. 468/ 9-11.

- Gonsalves Eric (2013): “The India-China Parleys (1979-1982)", Indian Foreign Affairs Journal, 10-12/2013.

- Goswami Namrata (2012): “China's Territorial Claim on Arunachal Pradesh", IDSA Occasional Paper no. 29.

- Haibin Niu (2013): "BRICS in Global Governance a Progressive and Cooperative Force?” Friedrich Ebert Stiftung, 9/2013;

- Hashmi Rehana: "China's ambitions abroad: The case of South Asia" IAPS Dialogue, 2/2018,

- Hass R. et al. (2017): “The Trajectory of Chinese Foreign Policy : From reactive assertiveness to opportunistic activism", Center for East Asia Policy Studies, Brookings Institute.

- Huntington Samuel P. (1957): The Soldier and the State: The Theory and Politics of Civil-Military Relations, Cambridge, 80-98, MA: Harvard University Press, the United States.

- Huntington, Samuel P. (1968): Political Order in Changing Societies, New Haven, Yale University Press, 1-2.

- J.A. Bader (2016): "How Xi Jinping Sees the World ... and Why", Asia Working Group, Foreign Policy, Brookings, 2/2016 
- Kui-wai Li (2001): “The Two Decades of Chinese Economic Reform compared”, APEC Study Centre City, University of Hong Kong, China and World Economy, No. 2.

- Lanteigne Marc (2009): "Who Makes Chinese Foreign Policy Today?", Chinese Foreign Policy: An Introduction, Routledge, London, 19.

- Miller Tom (2017): China's Asian Dream: Empire Building along the New Silk Road, Zed Books, London, 5-9.

- Morrison W.M. (2013): “China’s Economic Rise: History, trends, challenges, and implications for the United States", Library of Congress, Congressional Research Service, 2-37.

- Panda Jagannath (2018): “Xi Jinping’s Extended Presidency and India-China Relations", IDSA Issue Brief, 3/2018.

- Rewizorski M. (2015): “The European Union and the BRICS: Complex Relations in the Era of Global Governance, 1-180.

- Shambaugh David (2016): China's Future, Malden, MA: Polity Press, UK, 2-6.

- Stanzel Angela et al. (2017): "China's New Era with Xi Jinping's characteristics", European Council on Foreign Relations, 12/2017

- Svolik Milan (2009): "Power Sharing and Leadership Dynamics in Authoritarian Regimes," American Journal of Political Science 53, no. 2, 477-494.

- Swaine Michael D. (2010): «China’s Assertive Behavior Part One: On “Core Interests", China Leadership Monitor, no. 34, 8/2010.

- Talmadge Caitlin (2016): "Different Threats, Different Militaries: Explaining organizational practices in authoritarian regimes", Security Studies, 25:111-141.

- Xie Tao: “Chinese Foreign Policy with Xi Jinping Characteristics", Carnegie Endowment for International Peace, 11/2017.

- Yao Y. (2014): “A New Normal, but with Robust Growth: China's Growth Prospects in the Next 10 Years", 77-82.

- Zhang Feng (2017): "Chinese Thinking on the South China Sea and the Future of Regional Security”, Political Science Quarterly, 132: 3.

- Zhang Jian (2015): "China's New Foreign Policy under Xi Jinping: Towards 'Peaceful Rise 2.0'?” Global Change, Peace \& Security, 1, 5-19. 


\section{SI ĐINPINGOV AUTORITARIZAM, KINESKA SPOLJNA POLITIKA I INDIJA}

Kineski predsednik Si Đinping usredsredio se na konsolidaciju moći, fokusirajući se na domaće restrukturiranje kako bi učvrstio centralnost Komunističke partije Kine (KPK) i njenu komunističku ideologiju. Ovo je navelo političke analitičare da razmišljaju o tome da li je na snazi autoritarni kineski režim spoljne politike Si Đinpinga. Kina već pravi veliki regionalni pomorski napredak i koristi svoju ekonomsku moć nad svojom kontinentalnom periferijom. U tom smislu, rastu napetosti u indijsko-pacifičkom regionu sa zemljama poput Indije i Japana, koje se udružuju kako bi poništile dominaciju Kine. Bez obzira na to, nova sigurnosna arhitektura Azije zahteva uravnoteženo strateško manevrisanje, vidljivo na primeru Kine i Indije, koje unapređuju svoje bilateralne odnose, dok istovremeno sklapaju nove ugovore s drugim zemljama istog mišljenja.

Ključne reči: Si Đinping, autoritarnost, kineska spoljna politika, predsednički mandat Si Đipinga, spoljna politika Indije, indijsko-kineski odnosi 